\title{
Study on the Tax Enforcement of Deed Tax: From the Perspective of Digital Economy
}

\author{
Jiangyu Huang ${ }^{1}$, Xue Sheng ${ }^{1}$, Jing $\mathrm{Li}^{2,}$ * \\ ${ }^{1}$ College of Big Data Application and Economics, Guizhou University of Finance and Economics, Guiyang, China \\ ${ }^{2}$ Faculty of Management and Economics, Kunming University of Science and Technology, Kunming, China
}

Email address:

woshiqudeyiqie@163.com (Jing Li)

${ }^{*}$ Corresponding author

\section{To cite this article:}

Jiangyu Huang, Xue Sheng, Jing Li. Study on the Tax Enforcement of Deed Tax: From the Perspective of Digital Economy. International Journal of Accounting, Finance and Risk Management. Vol. 5, No. 4, 2020, pp. 207-212. doi: 10.11648/j.ijafrm.20200504.15

Received: December 5, 2020; Accepted: December 16, 2020; Published: December 22, 2020

\begin{abstract}
The digital economy puts forward new requirements for tax enforcement and risks of deed tax. Scholars rarely study deed tax enforcement from the perspective of taxpayer experience. This study combines the theory of tax compliance and uses questionnaire survey methods to explore the risks of deed tax enforcement under the background of big data and digital economy. Combining the characteristics of the digital economy, the study starts with the deed tax system, personnel, publicity methods, and tax awareness, with the goal of increasing taxpayers' tax compliance, and proposes suggestions for improving deed tax collection and management. In accordance with the requirements of the digital economy, the government should improve the policy system for the enforcement of deed tax. Governments, enterprises, universities, and individuals should strengthen cooperation and form partnerships, and attach importance to the training of talents that combine tax expertise and big data technology capabilities. Governments, schools, and companies use digital information platforms, artificial intelligence, and blockchain technology to enhance the effectiveness of publicity and implementation of deed tax enforcement. The interconnection of government information is conducive to reducing the digital divide and improving the effectiveness of enforcement. Big data is the basis for tax enforcement. Data governance emphasizes the digital transformation of government departments. Colleges and universities attach great importance to improving the tax data literacy and application capabilities of undergraduates, graduate students, and doctoral students.
\end{abstract}

Keywords: Deed Tax, Tax Enforcement, Digital Economy, Big Data Thinking, Data Application Ability

\section{Introduction}

The development of the digital economy has brought opportunities and challenges to tax enforcement. Deed tax is a one-time tax based on the contract and transaction price when the property rights of real property (land, house) change. The deed tax has the value of "increasing local fiscal revenue, promoting housing and land transaction management, and giving full play to community pension, childcare, and housekeeping services." Existing academic research focuses on the opportunities and challenges that the digital economy brings to tax collection and management. However, the existing research seldom studies the digital economy and deed tax collection and management issues, and seldom discusses the risks and improvements in deed tax enforcement from the perspective of taxpayers. According to the China Statistical Yearbook, China's deed tax revenue has shown a sustainable upward trend. With the acceleration of urbanization, the proportion of deed tax in local fiscal revenue is increasing. Deed tax revenue increased from 130.8 billion yuan in 2008 to 621.3 billion yuan in 2019, an increase of 4.75 times. The tax revenue of the deed tax in Guizhou Province has grown rapidly. Guizhou Province is an underdeveloped region in China. This study selects Guizhou Province for case analysis, which is typical and representative.

In the development of the digital economy, scholars seldom use field research and questionnaire survey methods to explore taxpayers' views on the effects of deed tax policy implementation and the regulation of tax enforcement. This research is based on the survey data of deed tax, and optimizes deed tax enforcement from the perspective of taxpayers. Deed 
tax is an important source of local fiscal revenue. The combination of digital economy and deed tax enforcement will be benefit for reducing the loss of national fiscal revenue.

The tax enforcement of deed tax helps protect the legitimate rights and interests of real estate owners. The adjustment of the deed tax rate affects real estate prices, and the deed tax plays a macro and micro role in the real estate market [1]. Some scholars have studied the flexibility of deed tax. The study found that there is little difference between the flexibility of deed tax in eastern and western China. The research suggests that different regions should adopt different policies according to the characteristics of deed tax [2]. Based on data sets and scientific taxation surveys, it is found that taxation affects individuals' overall attitudes towards future life and employment [3]. The object of deed tax can be discussed from the perspective of administrative adjudication [4].

An overview of big data and tax enforcement. Data has become the most active factor of production in economic and social development, and taxation governance is transforming to a smart organization with multiple collaborative governance and digital empowerment [5]. Big data technology has penetrated into tax management, and tax risk management has problems of poor data quality, insufficient analysis accuracy, and insufficient professionalism of managers. The big data platform ecosystem is a value network, which composed of products, services, and multiple entities, and has the characteristics of value co-creation [6]. The governance of the platform ecosystem needs to properly handle three basic relationships: standardization and diversity, control and autonomy, overall interests and individual interests [7]. The taxation department should conduct publicity and training on the tax enforcement of platform operators of the sharing economy (gig economy); effectively identify tax risks; and assist policy makers in formulating standardized guideline $[8,9]$.

Research on the Challenges and Responses of Digital Economy to Tax Governance. The digital economy promotes innovation in technology, systems, and business models. Digital economy integrates and balances tax governance structure, improves tax governance system, and optimizes tax governance methods [10]. Scholars are concerned about the tax challenges in the digital economy [11]. There are different opinions on whether the value creation of the digital economy environment can be used as the basis for the distribution of tax rights $[12,13]$. It is difficult to distinguish the difference between the impact of user participation on value creation in the digital economy and the traditional economy [14]. The platform economy is a new type of economic format spawned by modern information technology and has become an important engine for economic growth $[15,16]$. There are difficulties in tax governance of the platform economy. Scholar' research on taxation of the sharing economy and gig economy has reference value for the construction of taxation policies and enforcement systems $[17,18]$.

\section{Analysis of Problems in the Tax Enforcement of Deed Tax}

\subsection{Explanation of Research Methods}

This research mainly adopts questionnaire survey method and interview method. The questionnaire survey method is to conduct electronic questionnaire surveys of property owners in various regions of Guizhou, in order to discover the risks and problems of the combination of digital economy and deed tax enforcement. This study interviewed the staff of the tax authorities in Guizhou Province to understand the views of tax professionals on the risks and issues of deed tax enforcement. This questionnaire was conducted on a household basis, using the form of an online electronic questionnaire. Before the formal survey, this research conducted a preliminary survey of the questionnaire. The results of the preliminary survey found that the survey participants can better understand the content of the questionnaire.

After passing the questionnaire pre-survey test, this study distributed a large number of questionnaires in Guizhou Province, and finally got 300 valid questionnaires. Among the households surveyed by the questionnaire, men accounted for $37.33 \%$ and female accounted for $62.67 \%$. According to the educational level of the survey respondents, the proportion of junior high school education accounted for $6 \%$, high school education accounted for $7.67 \%$, university undergraduate education accounted for $83 \%$, and postgraduate education accounted for $3.33 \%$. In terms of age distribution, $87.33 \%$ of respondents are $20-30$ years old, $3.67 \%$ are $30-40$ years old, $7 \%$ are $40-50$ years old, and $1.33 \%$ are $50-60$ years old. The proportion of people over 60 years old is $0.67 \%$. The subjects of this survey are mainly real estate owners and tax authorities, mainly by telephone or online interviews.

\subsection{The Risks and Problems in the Tax Enforcement of Deed Tax}

\subsubsection{The Taxation Scope of Deed Tax Is Narrow}

The tax objects of the deed tax include the transfer of land use rights and the sale of houses. In the era of digital economy, the parking spaces of houses are managed intelligently. When people buy urban commercial houses, they may choose to rent or buy parking spaces. Table 1 shows that, $65 \%$ of homeowners will choose to buy parking spaces. $35 \%$ of owners will choose to rent a parking space, and $38 \%$ of them will choose $1-5$ years, $10.33 \%$ would choose $5-10$ years, $19.33 \%$ would choose more than 10 years. The existing deed tax policies do not specify whether a deed tax is imposed on parking spaces purchased or long-term leased by homeowners. The smart parking lot facilitates the life of the homeowner. Levying deed taxes on smart parking lots is an important trend in the development of the digital economy. 
Table 1. The owner's parking space selection method and rental duration.

\begin{tabular}{lll}
\hline & parking space selection method (percentage) & rental duration (Year/percentage) \\
\hline Purchase & $65 \%$ & $0-1(32.33 \%)$ \\
& & $1-5(38 \%)$ \\
Rental & $35 \%$ & $5-10(10.3 \%)$ \\
& & $10(19.33 \%)$ \\
\hline
\end{tabular}

\subsubsection{Tax Calculation Basis and Tax Liability Time Are Not Easy to Determine}

The difference in floor and location of real estate in various places makes the market value quite different. The digital economy puts forward new requirements for the evaluation of house value. The price evaluation of a house transaction cannot be determined solely based on the contract transaction price. The value of the transaction house and land should be comprehensively evaluated. In practice, there is a low contract transaction price, which causes a large loss of deed tax revenue. Second-hand housing transactions are frequent, and the under-reporting phenomenon in housing tax returns will cause the loss of tax revenue. The combination of taxation and big data information mechanisms needs to be improved, and the housing market price evaluation mechanism that is compatible with the development of the digital economy needs to be further improved. The time of deed tax payment obligations in the deed tax collection and management needs to be further clarified. The housing area in the pre-sale contract of commercial housing may be inconsistent with the actual housing area, and the determination of the obligation time for deed tax payment cannot effectively prevent the loss of tax.

\subsection{The Combination of Digital Economy and Taxation Promotion Needs to Be Improved}

Regarding the question of "whether the taxation department has done any Publicity on the deed tax collection and management", $13.67 \%$ of the people said they had done it, $25.33 \%$ of the people said they had not done it, and $61 \%$ of the people said they did not know. Regarding the question of "channels for obtaining information on deed tax collection and management", $48.33 \%$ of the survey respondents answered that they were real estate companies, and $43.67 \%$ of the survey respondents answered the government official website.

According to the questionnaire survey, in terms of deed tax information disclosure and publicity, the investigators have little understanding of tax enforcement requirements and deed tax information release channels.

The main Publicity mode of the deed tax: tax guides are set up in the tax business hall and propagated on the tax department website. The existing Publicity methods of the deed tax are less integrated with big data technology and digital economy, have a narrow scope of influence, and it is more difficult to pass information to groups that really need to know the information. The tax enforcement requirements of deed tax are not publicized in a timely manner, and taxation agencies do not provide adequate deed tax services and education for taxpayers, making it difficult for taxpayers to form effective deed tax compliance.

Taxpayers have insufficient understanding of the value and functions of the deed tax, which makes their taxpaying awareness weak.

It can be seen from survey data that $38.67 \%$ of the house owners agree to pay the deed tax when the property rights of real estate are transferred, $10.33 \%$ of the house owners think that it is not necessary to pay, and others say that they are not clear. Regarding the question of "whether the deed tax has been paid", $36 \%$ of the respondents said that they have paid, $12.67 \%$ of the respondents said that they have not paid, and $51.33 \%$ of the respondents said that they have paid the deed tax to the real estate developer. On the question of "whether they understand the current tax rate of deed tax", respondents who do not understand the tax rate account for a relatively large proportion; on the issue of "deed tax liability time", respondents who do not understand the regulations account for nearly $60 \%$.

According to survey data and interviews with tax agency staff, taxpayers' awareness of paying deed tax needs to be improved. Taxpayers' lack of tax awareness is caused by many reasons: the tax authorities' lack of publicity and depth, tax authorities and taxpayers' lack of information sharing, and insufficient use of big data technology. This will lead to low compliance with taxpayers' deed tax.

\subsection{The Professionalism of Deed Tax Enforcement Needs to Be Improved}

There are two main reasons for the low level of deed tax enforcement: On the one hand, deed tax is local tax revenue, local tax authorities have fewer staff, and the workload of tax collection and administration is relatively large. Deed tax is easy to be ignored. Tax officials responsible for the enforcement of deed tax for real estate development enterprises are under greater pressure. The tax bureau implements a corporate responsibility system. Usually, a tax cadre is responsible for one type of enterprise. The deed tax enforcement of real estate enterprises belongs to a tax cadre. The combination of big data and supervision is less, making it difficult to effectively improve the effect of tax governance. On the other hand, the staff in the lobby of the tax authorities are often labor dispatch employees. The education level and professionalism of labor dispatch employees need to be improved.

Tax enforcement staff are less trained in data literacy and data thinking. In practice, it is even more difficult to combine tax enforcement with big data technology. Deed tax enforcement involves many certification materials and cooperation departments. Insufficient informatization of 
cooperation among various departments increases the risk of identification of deed tax data. Due to the insufficient data sharing mechanism of various departments, this makes it difficult to reduce or exempt deed tax. Deed tax involves taxation departments, land departments, and real estate enterprises. The lack of an effective information exchange platform between government departments and enterprises will increase the risk of deed tax loss.

\section{Suggestions on Improving the Governance of Deed Tax Enforcement}

In the context of the development of the digital economy, there are risks and problems in the deed tax policy, deed tax publicity, and professionalism of enforcement. This study aims to improve the efficiency of deed tax enforcement and increase taxpayers' tax compliance, and mainly proposes three suggestions.

\subsection{Digital Economy Drives the Governance of Deed Tax Enforcement}

The digital governance of deed tax enforcement is an inevitable requirement for the development of the digital economy. Tax governance mainly involves the scope, tax calculation basis, tax payment obligation time, and legislative protection of deed tax enforcement. The taxation scope of the deed tax can focus on the lease and sale of parking spaces, and the long-term lease or transaction of smart parking spaces can be included through big data technology. This is conducive to reducing tax losses in the enforcement of deed tax and safeguarding local fiscal revenue.

With regard to the tax calculation basis of the deed tax, big data information technology can be used to establish a scientific housing and land transaction evaluation system. House value evaluation is inseparable from the true verification of prices. The tax calculation basis of the deed tax should be combined with the market transaction value. The deed tax enforcement agency uses big data platform of the real estate to scientifically determine the transaction prices of houses and land. The use of big data technology in deed tax enforcement can better reflect tax fairness and effectively reduce taxation costs. Information-based enforcement improves taxpayer' compliance with deed tax.

From the perspective of tax compliance, the combination of big data technology, artificial intelligence, blockchain, and deed tax enforcement can better remind taxpayers to perform their obligations in a timely manner. According to behavioral economics, smart tax liability reminders and information disclosure can improve the governance efficiency of tax enforcement.

Deed tax is a one-time tax enforcement when property rights change. The effective release of deed tax information can reduce taxpayers' tax payment risks. Taxpayers know the significance and value of deed tax enforcement, which will effectively enhance the legality and rationality of deed tax, and enhance taxpayers' institutional compliance. The application of big data in the deed tax enforcement will enhance the refinement of deed tax governance. Taxation governance of deed tax enforcement cannot be separated from taxation law. China's deed tax has been upgraded from regulations to laws, reflecting the rule of law and the emphasis on deed tax governance. The combined application of deed tax law and big data technology will effectively enhance the effect of deed tax enforcement.

\subsection{Data Empowers Deed Tax Enforcement and Improve Tax Compliance}

\subsubsection{Artificial Intelligence and Blockchain Enhance the Trust and Efficiency of Deed Tax Enforcement}

As the main driving force, artificial intelligence technology (AI) empowers all participating entities and business links in deed tax enforcement. AI technology plays an important role in simplifying and innovating the process of tax enforcement and upgrading services. Artificial intelligence, big data, cloud computing and blockchain jointly provide technical support for the transformation and upgrading of deed tax enforcement. Big data provides basic resources, cloud computing is the infrastructure, blockchain establishes the basic mechanism, and artificial intelligence is the core driving factor for the intelligentization of tax enforcement.

Traditional passive deed tax promotion makes it more difficult for taxpayers to know the meaning and value of deed tax payment. As the tax cost increases, taxpayers will tend not to pay taxes. In order to prevent tax risks, artificial intelligence is introduced for tax enforcement, and blockchain technology is used to reshape taxpayers' trust in taxation. Deed tax is essentially to protect the legal rights of taxpayers and protect property rights traders. As the basis for effective market competition, property rights need to be effectively endorsed by deed tax. Through intelligence and blockchain technology, taxpayers have a deep understanding of deed tax enforcement, and taxpayers have a conscious taxation awareness. Big data empowers tax enforcement, enabling tax authorities to adopt efficient methods to achieve targeted tax law Publicity.

\subsubsection{Blockchain Enhance Taxation Awareness and Regional Taxation Business Environment}

Blockchain technology is based on high-speed parallel distributed intelligent network computing technology, and promotes the leap-forward development of digital economy, digital governance, and tax enforcement by building a safe, environmentally friendly, efficient, intelligent, and scalable technology ecosystem.

The combination of blockchain and electronic invoices can effectively prevent the risks of invoice fraud and tax evasion. The empowerment of big data technology for tax enforcement is reflected in two aspects: On the one hand, the combination of blockchain and deed tax enforcement will improve the supervision of tax revenue; On the other hand, blockchain enhances the taxation business environment, and blockchain combines taxation credit with social credit. The taxation business environment driven by data will enhance the efficiency and quality of market competition supervision. 


\subsection{The Construction of Tax Management Talent System Driven by the Data Economy}

\subsubsection{Cultivate Tax Talents with Digital Thinking and Application Capabilities}

Digital professionals with tax expertise are the guarantee for the digital enforcement of deed tax. This requires collaboration and partnership between the governments, universities, enterprises, and individuals. When the government recruits tax personnel, it should focus on the data literacy of talents; the education authority strengthens big data courses and encourages universities to develop courses related to big data thinking and application ability. Colleges and universities should strengthen the construction of digital taxation courses, especially the digital-oriented teacher training. The university attaches importance to the digital literacy of students, and cultivates application talents with dual abilities of taxation and digitalization. Based on professional characteristics, the School of Finance and Taxation builds a digital taxation curriculum system and strengthens curriculum cooperation with the School of Statistics and the School of Information. When recruiting talents, companies should pay attention to the data-based thinking and capabilities of talents, and drive the company's digital transformation with data orientation. In terms of personal development, individuals should establish a good career goal combining data and professionalism. Individuals should have data element thinking on big data, artificial intelligence, blockchain, digital economy, and new infrastructure. Individuals participate in data-based application scenarios, combine professional capabilities with data application capabilities, and enhance their own competitiveness in the labor market. The tax department should strengthen the deed tax enforcement personnel, and make full use of big data technology, blockchain, and artificial intelligence in the enforcement of deed tax.

The taxation department optimizes the structure of grassroots taxation personnel to create a professional and efficient deed tax enforcement team. First, the tax department recruits excellent professional tax personnel, so that the number of grassroots tax personnel matches the workload of tax enforcement. Secondly, tax authorities will strengthen professional skills and professional ethics training for grassroots tax staff, and taxpayers will enhance the trust of tax authorities.

\subsubsection{Strengthen the Interconnection of Information Among Taxation Departments and Reduce the Digital Divide}

The efficiency of deed tax enforcement requires effective cooperation from various departments. The interconnection of government information in tax enforcement helps to identify tax-related information and prevent the risk of tax loss. The deed tax enforcement involves housing agencies, land departments, and real estate companies. To improve coordination between departments, attention should be paid to the interconnection of information: On the one hand, in order to improve the authenticity of deed tax data and ensure data quality, information and data platforms should be built between departments to realize information sharing and data application, and improve the efficiency of each department. On the other hand, big data should facilitate the supervision of the deed tax enforcement by the supervision department, guarantee the authority of deed tax enforcement, and enhance taxpayers' tax compliance.

\section{Conclusion}

The digital economy brings opportunities and challenges to tax enforcement. This research takes the deed tax enforcement as the core of the research, combined with the analysis of the deed tax survey data in Guizhou Province, China. The study found that there is a problem of information management tax in the collection and management of deed tax. Based on the problem analysis, this article discusses measures to combine with tax enforcement from the aspects of big data technology, blockchain, and artificial intelligence. Governments, enterprises, and universities attach importance to the training and recruitment of talents, and actively carry out digital transformation and digital governance. This research has theoretical and practical value for the research of digital economy and tax enforcement.

\section{Acknowledgements}

This research is financially supported by "Research on Cultivation of Big Data Thinking and Application Ability of University Undergraduates: Based on the Perspective of Digital Economy" (GZJG20200203).

\section{References}

[1] Jiangyu Huang, Kezhen Liu (2020). Research on Tax Planning of PPP Projects in China: Based on the Perspective of Digital Economy, Journal of Finance Research, 4 (02): 128-134.

[2] Hong Z (2011). The analysis of deed tax elasticity in China, International Conference on E-business \& E-government. IEEE.

[3] Petutschnig M (2017). Future orientation and taxes: Evidence from big data. Journal of International Accounting, Auditing and Taxation.

[4] Dachis B, Duranton G, Turner M A (2011). The effects of land transfer taxes on real estate markets: evidence from a natural experiment in Toronto. Journal of Economic Geography.

[5] Olbert M, Spengel C (2019). Taxation in the Digital Economy -Recent Policy Developments and the Question of Value Creation. SSRN Electronic Journal.

[6] Arias-Arevalo P, et al (2018). Widening the Evaluative Space for Ecosystem Services: A Taxonomy of Plural Values and Valuation Methods. Environmental Values, 27 (1): 29-53.

[7] Wareham J, Fox P B, Cano Giner J L (2014). Technology ecosystem governance. Organization Science, 25 (4): $1195-1215$. 
[8] OECD (2018). Tax Challenges Arising from DigitalisationInterim Report 2018, Paris: OECD Publishing, 140-147.

[9] OECD (2019). The Sharing and Gig Economy: Effective Taxation of Platform Sellers, Paris OECD Publishing, 18.

[10] Tiwana A, Konsynski B, Bush A A (2010). Research Commentary-Platform Evolution: Coevolution of Platform Architecture, Governance, and Environmental Dynamics. Information Systems Research, 1 (4): 675-687.

[11] OECD (2016). Technologies for Better Tax Administration: A Practical Guide for Revenue Bodies, Paris: OECD Publishing.

[12] OECD (2015). Addressing the Tax Challenges of the Digital Economy: Action 1-2015 Final Report, Paris: OECD Publishing, 116.

[13] Danescu E (2020). Taxing intangible assets: issues and challenges for a digital Europe. Internet Histories, (1): 1-21.
[14] Ge Y, Dollar D, Yu X (2020). Institutions and participation in global value chains: Evidence from belt and road initiative. China Economic Review, 61: 1-14.

[15] Su Wenning, Hu Qinzhong, Yin Shouming (2015). Suggestions on Improving the Management and Collection of Deed Tax. Taxation Research, 2015 (10): 74-77.

[16] Lemons, M (2012). Circuit Breakers: Implementing a Property Tax Credit to Help Low-Income Households, Georgetown Journal on Poverty Law \& Policy.

[17] Wood A, Lehdonvirta V (2019). Platform Labour and Structured Antagonism: Understanding the Origins of Protest in the Gig Economy. SSRN Electronic Journal.

[18] OECD (2020). Code of Conduct: Co-operation between Tax Administrations and Sharing and Gig Economy Platforms, Paris: OECD Publishing. 